\title{
UPPER GASTROINTESTINAL BLEEDING: IS ONLY AN INJECTION OF EPINEPHRINE SUFFICIENT? SUCCES RATES BY FORREST CLASSIFICATION
}

\author{
Surek Ahmet, Gemici Eyup, Bozkurt Abdussamet Mehmet, Karabulut Mehmet \\ University of Health Sciences, Faculty of Medicine, Bakirkoy Dr. Sadi Konuk \\ Health Practice and Research Center, Department of General Surgery, Istanbul, Turkey
}

Primljen/Received 27. 07. 2020. god.

Abstracts: Objective: Endoscopic treatment is an effective and successful treatment for non-variceal upper gastrointestinal system (GIS) bleedings. In recent years, endoscopic combined therapies have been recommended for hemostasis. The aim of this study was to investigate primary hemostasis rates and re-bleeding rates obtained by epinephrine injection alone.

Material and Methods: We analysed patients who had alone endoscopic epinephrine injection treatment for upper gastrointestinal system bleeding between January 2014 and January 2019. Gender, age, etiology of bleeding, Forrest classification, treatment efficacy and re-bleeding rates of the patients were recorded. The files of the patients were analyzed retrospectively. Results: The number of patients who met the study criteria was 107 . There were 16 patients in Group 1 (Forrest 1a), 64 patients in Group 2 (Forrest 1b) and 27 patients in Group 3 (Forrest 2a). Primary hemostasis was achieved in $14(87.5 \%)$ of 16 patients in Group 1, 62 (97\%) of 64 in Group 2, and $27(100 \%)$ of 27 Group 3. Re-bleeding rates were 4 (28\%), 10 (16\%), $2(7 \%)$ in groups 1,2 and 3 , respectively.

Conclusion: It is thought that endoscopic combined treatment should be applied especially in patients with Forrest 1a and 1b bleeding ulcers, whereas in Forrest $2 \mathrm{a}$ ulcer patients, because of both the high rate of primary hemostasis and low rate of re-bleeding according to the results of the present study, the treatment of adrenalin injection alone can be used alone like other hemostasis modalities.

Key words: Endoscopic treatment, Forrest classification, upper gastrointestinal bleeding.

\section{INTRODUCTION}

Upper gastrointestinal system bleeding has an incidence ranging from 48 to 160 cases per 100.000 peo-
Prihvaćen/Accepted 13. 10. 2020. god.

ple, depending on geographical regions. It is more common in men and in the elderly population. Different incidences between populations can be explained by various reasons such as drug-induced ulcers and the prevalence of Helicobacter Pylori $(1,2)$.

The peptic gastroduodenal ulcer is the most common cause of non-variceal upper gastrointestinal bleeding. Mallory-Weiss Syndrome, vascular abnormalities, iatrogenic bleedings after endoscopic procedures and bleedings at the surgical site can be given as other causes (3). Mortality due to upper gastrointestinal bleeding is associated with advanced age and accompanying comorbidities. The risk of mortality increases with recurrent bleeding (4). Despite the use of therapeutic endoscopy and gastric acid suppressors for optimal treatment, it is seen that the mortality rate has remained constant between $6 \%$ and 14\% in recent years (5).

Endoscopic treatment is an effective and successful treatment for non-variceal upper gastrointestinal system (GIS) bleedings (6). Endoscopic treatment can significantly reduce the risk of bleeding or ongoing bleeding, the need for surgery, the number of packed erythrocyte units required for transfusion, and the length of hospital stay $(6,7)$.

Endoscopic hemostasis can be achieved using injection, and thermal and mechanical methods. Epinephrine, sclerosing agents (ethanol, ethanolamine, polidocanol) and thrombin/fibrin glue can be used in the treatment of injection $(8,9,10)$.

\section{AIM}

The present study aims to investigate the primary hemostasis success rates and re-bleeding rates of upper gastrointestinal system bleedings, which are stopped by epinephrine injection alone as an endoscopic 
treatment, according to the Forrest classification sub-groups.

\section{MATERIAL AND METHOD}

Patients who had endoscopic epinephrine injection treatment for upper gastrointestinal system bleeding between January 2014 and January 2019 in the general surgical endoscopy unit of Bakırköy Dr. Sadi Konuk Training and Research Hospital and had an endoscopic bleeding index of Forrest $1 \mathrm{a}, 1 \mathrm{~b}$ and $2 \mathrm{a}$ were included in this study. The files of the patients were analyzed retrospectively. Gender, age, etiology of bleeding, treatment efficacy and re-bleeding rates of the patients were recorded. The Forrest classification was used as an endoscopic bleeding index (Table 1). Patients were divided into three groups according to the Forrest classification. Patients in Group 1 were classified as those having Forrest 1a, patients in Group 2 as those having Forrest 1b, and patients in Group 3 as those having Forrest $2 \mathrm{a}$ endoscopic bleeding index. Primary hemostasis success and re-bleeding rates of endoscopic injection treatment according to Forrest classification were reviewed. Hemodynamic deterioration, active hematochezia and a decrease of $2 \mathrm{~g} / \mathrm{dl}$ or more in hemoglobin values within 24 hours during the follow-up of the patients who were provided hemostasis with the first endoscopic treatment

Table 1. Description of Forrest classification

\begin{tabular}{|l|l|}
\hline \multicolumn{1}{|c|}{$\begin{array}{c}\text { Forrest } \\
\text { classification }\end{array}$} & \multicolumn{1}{c|}{ Description } \\
\hline Forrest $1 \mathrm{a}$ & Spurting hemorrhage \\
\hline Forrest $1 \mathrm{~b}$ & Oozing hemorrhage \\
\hline Forrest $2 \mathrm{a}$ & Non-bleeding visible vessels \\
\hline Forrest $2 \mathrm{~b}$ & Adherent clot \\
\hline Forrest $2 \mathrm{c}$ & Flat pigmented spot \\
\hline Forrest 3 & Clean ulcer base \\
\hline
\end{tabular}

were evaluated as re-bleeding and it was determined that the endoscopic procedure was repeated. Epinephrine of $1 / 10000$ was used as the injection treatment. Those with $2 \mathrm{~b}, 2 \mathrm{c}$, and 3 endoscopic bleeding indexes according to Forrest classification, those using oral anticoagulants, those who have non-peptic ulcer bleeding causes in the etiology, and those with marginal ulcer and malignancy in gastrojejunostomy anastomosis were excluded from the study.

All procedures performed in this study, involving human participants were in accordance with the 1964 Helsinki declaration and its latest amendments or comparable ethical standards. Informed consent was obtained from all individual participants of the study.

\section{RESULTS}

It was seen that 536 patients underwent endoscopy for upper gastrointestinal bleeding in the endoscopy unit between 2014 and 2019. In 414 (77\%) of these patients, gastroduodenal ulcer (49\% duodenal ulcer, 28\% gastric ulcer) bleeding was detected. The number of patients who met the study criteria was 107 . There were 16 patients in Group 1 (Forrest 1a), 64 patients in Group 2 (Forrest $1 \mathrm{~b}$ ) and 27 patients in Group 3 (Forrest 2a).

The F/M ratio in the gender distribution of Group 1 was $4 / 12(25 \%, 75 \%)$ and the mean age was $59(20-82)$. The F/M ratio in the gender distribution of Group 2 was $14 / 50(22 \%, 78 \%)$ and the mean age was $61.6(19-90)$ years. The $\mathrm{F} / \mathrm{M}$ ratio in the gender distribution of Group 3 was $8 / 19(29 \%, 71 \%)$ and the mean age was 59 (28-84). In the overall series, the F/M ratio was $26 / 81$ $(24 \%, 76 \%)$ and the mean age was 59.9 (Table 2 ).

When the etiology of bleeding was examined, 5 patients had gastric ulcer and 11 patients had duodenal ulcer bleeding in Group 1, 9 patients had gastric ulcer and 55 patients had duodenal ulcer bleeding in Group 2 , and 4 patients had gastric ulcer and 23 patients had duodenal ulcer bleeding in Group 3 (Table 3).

Table 2. Demographic data

\begin{tabular}{|l|c|c|c|c|}
\hline & Patient, $\mathbf{n ( \% )}$ & Female & Male & Mean Age (SD) \\
\hline Group 1 & $16(15 \%)$ & $4(25 \%)$ & $12(75 \%)$ & $59(17.53)$ \\
\hline Group 2 & $64(59 \%)$ & $14(22 \%)$ & $50(78 \%)$ & $61.6(16.68)$ \\
\hline Group 3 & $27(26 \%)$ & $8(29 \%)$ & $19(71 \%)$ & $59(16.60)$ \\
\hline Total & $107(100 \%)$ & $26(24 \%)$ & $81(76 \%)$ & $59.9(17.16)$ \\
\hline
\end{tabular}

Table 3. Etiology

\begin{tabular}{|l|c|c|c|}
\hline & Gastric ulcer, n(\%) & Duodenal ulcer, n(\%) & Total \\
\hline Group 1 & $5(31 \%)$ & $11(69 \%)$ & 16 \\
\hline Group 2 & $9(14 \%)$ & $55(86 \%)$ & 64 \\
\hline Group 3 & $4(15 \%)$ & $23(85 \%)$ & 27 \\
\hline Total & $18(17 \%)$ & $89(83 \%)$ & 107 \\
\hline
\end{tabular}


Table 4. Primary hemostasis success rates

\begin{tabular}{|l|c|c|c|}
\hline & Hemostasis, $\mathbf{n}(\mathbf{\%})$ & Non-hemostasis, $\mathbf{n}(\mathbf{\%})$ & Total \\
\hline Group 1 & $14(87.5 \%)$ & $2(12.5 \%)$ & 16 \\
\hline Group 2 & $62(97 \%)$ & $2(3 \%)$ & 64 \\
\hline Group 3 & $27(100 \%)$ & 0 & 27 \\
\hline Total & $103(96.2 \%)$ & $4(3.8 \%)$ & 107 \\
\hline
\end{tabular}

Table 5. Repeat endoscopy and re-bleeding rates

\begin{tabular}{|l|c|c|}
\hline \multicolumn{1}{|c|}{ Groups, (n) } & Re-endoscopy rate, $\mathbf{n ( \% )}$ & Re-bleeding rate, $\mathbf{n ( \% )}$ \\
\hline Group 1, (14) & $4(28 \%)$ & $4(28 \%)$ \\
\hline Group 2, (62) & $16(26 \%)$ & $10(16 \%)$ \\
\hline Group 3, (27) & $3(11 \%)$ & $2(7.4 \%)$ \\
\hline Total (103) & $23(22.3 \%)$ & $16(15.5 \%)$ \\
\hline
\end{tabular}

When the treatment success rates were examined, it was seen that primary hemostasis was achieved in 14 (87.5\%) of 16 patients but endoscopic hemostasis could not be achieved in $2(12.5 \%)$ patients in Group 1. In the Group 2, however, primary hemostasis was achieved in $62(97 \%)$ patients but endoscopic hemostasis could not be achieved in $2(3 \%)$ patients. Four patients for whom primary hemostasis could not be achieved were operated. In Group 3, primary hemostasis was achieved in all 27 patients and the success rate was $100 \%$. Primary hemostasis was achieved in $103(96.2 \%)$ of 107 patients in all three groups. In Group 3, primary hemostasis was achieved in all 27 patients and the success rate was $100 \%$ (Table 4 ).

Considering the re-bleeding rates, it was seen that 4 (28\%) of 14 patients in Group 1 who had primary hemostasis underwent endoscopy again and 3 patients were re-treated with endoscopic injection and 1 patient was taken into operation due to $4(28 \%)$ patients had bleeding. In group 2, it was seen that endoscopy was repeated in $16(26 \%)$ of 62 patients with primary hemostasis, 10 (16\%) patients had re-bleeding, and 6 patients had no active bleeding. It was seen that 7 of 10 patients were given injection treatment again, 1 patient was applied clip, and 1 patient was treated with argon coagulation. One patient underwent surgery. In Group 3 , however, endoscopy was repeated in 3 of the 27 patients and 2 (7.4\%) of these 3 patients had bleeding in the form of leakage from the ulcer and the injection was re-administered. The endoscopic intervention was not performed in 1 patient since there was no bleeding (Table 5).

When examining the general results of the patients included in the study, it was found that a total of 6 (7.5\%) of the 80 patients in Forrest 1a and 1b groups with bleeding ulcer were operated after their first and repeated endoscopy applications. In repeat endoscopy procedures, 1 patient underwent clips and 1 patient underwent argon coagulation, while 72 patients were treated endoscopically with epinephrine injection alone. Of these 72 patients, 10 had endoscopic epinephrine injection treatment on endoscopies for a second time, leading to hemostasis, and $62(77.5 \%)$ had no need for a second procedure after primary hemostasis. None of the patients with visible vessels in the Forrest 2a group required surgery, and only $2(7.5 \%)$ patients underwent repeated injections.

\section{DISCUSSION}

The most common cause of non-variceal acute upper gastrointestinal system bleeding is peptic ulcer bleeding, which is observed between the rates of $28 \%$ and $59 \%$. Duodenal ulcer rate is seen between $17 \%$ and $37 \%$ and gastric ulcer rate is between $11 \%$ and $24 \%$ (11). In the present study, the rate of peptic ulcer $(49 \%$ duodenal ulcer, $28 \%$ gastric ulcer) was $77 \%(414 / 536)$ in endoscopies performed due to GIS bleeding and this result was higher when compared with the studies in the literature.

Studies have shown that endoscopic treatments improve clinical outcomes in GIS bleeding. Endoscopic treatment, especially in patients with high-risk bleeding lesions, significantly reduces the frequency of recurrence bleeding, the need for surgical intervention, and mortality $(6,12,13)$.

Considering the timing of endoscopy, it has been reported that emergency endoscopy performed within 24 hours reduces the risk of mortality and surgical intervention in patients with high-risk upper gastrointestinal system bleeding. However, in many studies, there was no significant difference between patients who un- 
derwent endoscopy within the first 24 hours and within the first 12 hours. Therefore, emergency endoscopy is recommended for patients suspected of upper gastrointestinal bleeding within the first 24 hours (14-17). In the present study, it was found that $96 \%(102 / 107)$ of the patients underwent endoscopy within 24 hours after admission.

Endoscopic hemostasis can be achieved by injection, and by thermal and mechanical methods. Epinephrine injection can be carried out with the applications of sclerosing agents, thrombin/fibrin glue applications, thermal contact (Heater probe thermocoagulation) and non-contact (Argon plasma coagulation) devices and mechanical clip application. Epinephrine injection provides vasoconstriction while sclerosing agents help to achieve hemostasis by providing thrombosis $(9,11,18)$.

Forrest classification was developed more than 40 years ago to standardize gastroduodenal ulcer bleedings. This classification has been used in numerous studies aimed at identifying patients at risk of persistent ulcer bleeding, re-bleeding, and death. Most of these studies have shown that the presence of ulcers classified endoscopically as F1a or F1b is an independent risk factor for permanent bleeding or re-bleeding $(11,19,20)$. In the literature, the rates of rebleeding was reported vary between $90 \%$ for a Forrest I a lesion and $5 \%$ for a Forrest III lesion (21).

In the literature, it is stated that hemostasis is achieved in the rates of over $90 \%$ with endoscopy in non-variceal upper gastrointestinal bleeding cases (22). In a study by Park et al., hemostasis rate achieved only by epinephrine injection was $97.7 \%$ in patients with bleeding ulcers, and hemostasis success rate achieved by combined treatment with epinephrine injection + mechanical clip was $97.7 \%$, and no difference was found between these rates (23). In a study by Gugliemi et al, in patients with Forrest 1a, 1b, 2a and 2b ulcers, the primary hemostasis rate by epinephrine and sclerosing agent injection with endoscopy was reported to be $95.6 \%(20)$. In the present study, primary hemostasis rates were $87.5 \%(14 / 16)$ in Forrest 1a and $97 \%(62 / 64)$ in Forrest $1 \mathrm{~b}$. In Forrest 2a, however, $100 \%$ hemostasis was achieved, and the overall primary hemostasis success rate was $96.2 \%(103 / 107)$ in all three groups. Comparing these rates with both non-epinephrine injection monotherapy treatment modalities and combined treatment modalities, results like those in the literature were found in terms of ensuring primary hemostasis.

In non-variceal upper GIS bleedings, the rate of re-bleeding after endoscopic treatment has been reported to be approximately $24 \%$ in the literature (24). In randomized studies, initial hemostasis rates were at approximately $90 \%$ with endoscopic monotherapy treat- ments without taking the hemostatic method into account, and re-bleeding rates were reported to be between $2 \%$ and $10 \%$ in endoscopic monotherapies other than epinephrine injection. There was no significant difference between monotherapies in ensuring initial hemostasis. Although epinephrine injection is effective in ensuring initial hemostasis in patients with active ulcer bleeding, the rate of re-bleeding has been reported to be between $12 \%$ and $30 \%(25-28)$.

In a study by Park et al., the rate of re-bleeding in patients with Forrest 1a, 1b, and 2a ulcers was found to be $20.4 \%(9 / 44)$ in the group where hemostasis was achieved only by epinephrine injection. In the combined treatment group, however, this rate was found to be $4.5 \%(2 / 44)(23)$. In another study by Pescatore et al., re-bleeding rates were $57 \%$ for Forrest 1a, $24 \%$ for Forrest $1 \mathrm{~b}$, and $21 \%$ for Forrest $2 \mathrm{a}$ in patients with GIS bleeding for whom hemostasis was achieved epinephrine alone, while the re-bleeding rates were reported as $25 \%$ for Forrest $1 \mathrm{a}, 14 \%$ for Forrest $1 \mathrm{~b}$ and $25 \%$ for Forrest $2 \mathrm{a}$ for the combined treatment of epinephrine + fibrin glue. In this study, the combined treatment significantly reduced re-bleeding rates in Forrest $1 \mathrm{a}$ and $1 \mathrm{~b}$ ulcers but did not achieve a decrease in re-bleeding rate in Forrest 2a (28).

In a prospective randomized study by Chu-Lo et al., patients receiving epinephrine injection alone were compared with patients receiving combined therapy with epinephrine and hemoclip, and re-bleeding rates were reported as $21 \%$ in patients receiving monotherapy and as $3.8 \%$ in patients receiving combined therapy. The need for emergency surgery was observed only in the group treated with epinephrine and was found to be $9 \%$ (29). In a review, re-bleeding and the need for surgery were observed less in patients who received endoscopic combined therapy than patients who received endoscopic monotherapy (30). Gugliemi et al. reported the re-bleeding rates in patients with upper GIS bleeding who were provided hemostasis with epinephrine and sclerosing agents as $23.6 \%$ for Forrest 1a, as $19 \%$ for Forrest $1 \mathrm{~b}$, and as $19.5 \%$ for Forrest $2 \mathrm{a}$ (20). In the present study, however, re-bleeding rates were 28\% (4/14) for Forrest 1a ulcer, 16\% (10/62) for Forrest $1 \mathrm{~b}$ ulcer, and $7.4 \%$ (2/27) for Forrest $2 \mathrm{a}$ ulcer and the re-bleeding rate of the overall series (group $1+2+3)$ was determined as $15.5 \%(16 / 103)$.

When the re-bleeding rates in the study were compared with other hemostatic methods except for epinephrine, these rates were found to be higher in patients with Forrest $1 \mathrm{a}$ and $1 \mathrm{~b}$ ulcers than in the literature, but they were found to be similar to those in the literature when compared with the results of the studies where epinephrine injection treatment was administered alone. Re-bleeding rates were lower in patients 
with Forrest $2 \mathrm{a}$ ulcers when compared to the results of the studies in the literature where epinephrine injections were administered alone, but these rates were found to be similar with the results obtained when compared with other non-epinephrine hemostasis methods. The re-bleeding rates of the general series of the present study $(15.5 \%)$ were found to be consistent with the literature.

When the re-bleeding rates in patients with Forrest $1 \mathrm{a}$ and Forrest $1 \mathrm{~b}$ ulcers were compared with the rates of re-bleeding after combined treatment, these rates were found to be higher than those in the literature. In patients with Forrest 2 a ulcer, however, when the rates of re-bleeding were compared with the rates of re-bleeding in combined treatment, they were found to be similar to those in the literature. In the present study, the rate of patients who needed urgent surgery was $5.7 \%$ and this rate was lower than the rate of surgical need in patients who underwent monotherapy in the literature, while it was similar to the rate of surgery need in studies where the combined therapy was administered.

The American Society for Gastrointestinal Endoscopy and European Society for Gastrointestinal Endoscopy guidelines recommend the administration of endoscopic treatment for classes Forrest $1 \mathrm{a}$ and $1 \mathrm{~b}$ with bleeding ulcers and ulcers with bleeding but not visible vessels in class Forrest $2 \mathrm{a}(11,22)$. In the guidelines, the administration of a second hemostasis modality with ESGE epinephrine injection is recommended, whereas epinephrine injection alone is not recommended in the classes Forrest 1a and 1b. In Forrest 2a, however, while mechanical, thermal or sclerosing agents were recommended to be administered as monotherapy or in combination with epinephrine injection, epinephrine injection alone was not recommended (11).

\section{CONCLUSION}

In conclusion, although adrenaline injection as an endoscopic treatment in GIS bleeding has a high success rate in achieving primary hemostasis, as discussed above, re-bleeding rates are higher than those in combined therapies. Therefore, it is thought that endoscopic combined treatment should be applied especially in patients with Forrest $1 \mathrm{a}$ and $1 \mathrm{~b}$ bleeding ulcers, whereas in Forrest 2a ulcer patients, because of both the high rate of primary hemostasis and low rate of re-bleeding according to the results of the present study, the treatment of adrenalin injection alone can be used alone like other hemostasis modalities.

Disclaimers: The authors state that the article is original, has not been submitted for publication in other journals and has not yet been published either wholly or in part. The authors state that all authors are responsible for the research that all authors have designed and carried out; that all authors have participated in drafting and revising the manuscript submitted, whose contents we approve.

Conflict of Interests: The authors declare that there are no conflicts of interest related to this article.

Funding: None

\section{Licensing}

This work is licensed under a Creative Commons Attribution 4.0 International (CC BY 4.0) License.

\title{
Sažetak
}

\section{KRVARENJE IZ GORNJIH PARTIJA GASTROINTESTINALNOG TRAKTA: DA LI JE SAMO INJEKCIJA EPINEFRINA DOVOLJNA? STOPE USPEHA PO FORREST-OVOJ KLASIFIKACIJI}

\author{
Surek Ahmet, Gemici Eyup, Bozkurt Abdussamet Mehmet, Karabulut Mehmet \\ University of Health Sciences, Faculty of Medicine, Bakirkoy Dr. Sadi Konuk \\ Health Practice and Research Center, Department of General Surgery, Istanbul, Turkey
}

Uvod: Endoskopski tretman je efektivan i uspešan vid lečenja nevarikoznih krvarenja iz gornjih partija gastrointestinalnog trakta (GIT). Poslednjih godina, endoskopska kombinovana terapija je preporuka za hemostazu. Cilj ove studije bio je da ispita stope primarne hemostaze i ponovljenog krvarenja koji su tretirani samo injekcijom epinefrina.

Materijal i Metode: Analizirali smo pacjente koji su endoskopski dobili injekciju epinefrina kao jedini tretman zbog krvarenja iz gornjeg GIT-a između januara 2014. i januara 2019. Pol, godine starosti, etiologija krvarenja, Forrest-ova klasifikacija, efikasnost tretmana i stopa ponovljenog krvarenja su evidentirani. Istorije pacijenata su analizirane retrospektivno.

Rezultati: Broj pacijenata uključenih u studiju bio je 107. U Grupi 1 (Forrest 1a) bilo je 16, u Grupi 2 (Forrest 1b) 64 pacijenta, i u Grupi 3 (Forrest 2a) 27. Primarna hemostaza je postignuta kod $14(87,5 \%)$ od 
16 pacijenata u Grupi 1, 62 (97\%) od 64 u Grupi 2, i 27 $(100 \%)$ of 27 u Grupi 3. Ponovnih krvarenja je bio 4 (28\%), 10 (16\%), 2 (7) u grupama 1, 2 i 3.

Zaključak: Prema rezultatima studije smatra se da bi kombinovani endoskopski tretman trebalo primeniti posebno kod pacijenata sa Forrest 1a i 1b krvarećih ul-

\section{REFERENCES}

1. Tielleman T, Bujanda D, Cryer B. Epidemiology and risk Factors for upper gastrointestinal bleeding. Gastrointest Endosc Clin N Am. 2015; 25(3): 415-28.

2. Holster IL, Kuipers EJ. Management of acute nonvariceal upper gastrointestinal bleeding: current policies and future perspectives. World J Gastroenterol. 2012; 18(11): 1202-7.

3. Fujishiro M, Iguchi M, Kakushima N, Kato M, Sakata $\mathrm{Y}$, Hoteya $\mathrm{S}$, et al. Guidelines for endoscopic management of non-variceal upper gastrointestinal bleeding. Dig Endosc. 2016; 28(4): 363-78.

4. Holster IL, Kuipers EJ. Update on the endoscopic management of peptic ulcer bleeding. Curr Gastroenterol Rep. 2011; 13(6): 525-31.

5. Indonesian Society of Gastroenterology. National consensus on management of non-variceal upper gastrointestinal tract bleeding in Indonesia. Acta Med Indones. 2014; 46(2): 163-71.

6. Naseer M, Lambert K, Hamed A, Ali E. Endoscopic advances in the management of non-variceal upper gastrointestinal bleeding: A review. World J Gastrointest Endosc. 2020; 12(1): $1-16$.

7. Szura M, Pasternak A. Upper non-variceal gastrointestinal bleeding - review the effectiveness of endoscopic hemostasis methods. World J Gastrointest Endosc 2015; 7(13): 1088-95.

8. Jang JY. Recent Developments in the endoscopic treatment of patients with peptic ulcer bleeding. Clin Endosc. 2016; 49(5): 417-20.

9. Cipolletta L, Cipolletta F, Granata A, Ligresti D, Barresi $\mathrm{L}$, Tarantino I, et al. What is the best endoscopic strategy in acute non-variceal gastrointestinal bleeding? Curr Treat Options Gastroenterol. 2018; 16(4): 363-75.

10. Barkun AN, Almadi M, Kuipers EJ, Laine L, Sung J, Tse F, et al. Management of nonvariceal upper gastrointestinal bleeding: guideline recommendations from the international consensus group. Ann Intern Med. 2019; 171(11): 805-22.

11. Gralnek IM, Dumonceau JM, Kuipers EJ, Lanas A, Sanders DS, Kurien M, et al. Diagnosis and management of nonvariceal upper gastrointestinal hemorrhage: European Society of Gastrointestinal Endoscopy (ESGE) Guideline, Endoscopy. 2015; 47: 1-46.

12. Jung K, Moon W. Role of endoscopy in acute gastrointestinal bleeding in real clinical practice: An evidence-based review. World J Gastrointest Endosc. 2019; 11(2): 68-83.

13. Konstantinidis A, Valatas V, Ntelis V, Balatsos V, Karoumpalis I, Hatzinikoloaou A, et al. Endoscopic treatment for high-risk bleeding peptic ulcers: a comparison of epinephrine alone with epinephrine plus ethanolamine. Ann Gastroenterol. 2011; 24(2): 101-7.

14. Jairath V, Kahan BC, Logan RF, Hearnshaw SA, Doré CJ, Travis SP, et al. Outcomes following acute nonvariceal up- kusa, dok kod Forrest 2a pacijenata, zbog visoke stope primarnih hemostaza i niske stope ponovljenih krvarenja, tretman samo injekcijom adrenalina je dovoljan.

Ključne reči: endoskopski tretman, Forrest-ova klasifikacija, krvarenje iz gorneg gastrointestinalnog trakta.

per gastrointestinal bleeding in relation to time to endoscopy: results from a nationwide study. Endoscopy. 2012; 44(8): 723-30.

15. Cho SH, Lee YS, Kim YJ, Sohn CH, Ahn S, Seo DW, et al. Outcomes and role of urgent endoscopy in high-risk patients with acute nonvariceal gastrointestinal bleeding. Clin $\mathrm{Ga}-$ stroenterol Hepatol. 2018; 16(3): 370-7.

16. Hearnshaw SA, Logan RF, Lowe D, Travis SP, Murphy MF, Palmer KR. Use of endoscopy for management of acute upper gastrointestinal bleeding in the UK: results of a nationwide audit. Gut. 2010; 59(8): 1022-9.

17. Alexandrino G, Domingues TD, Carvalho R, Costa MN, Lourenço LC, Reis J. Endoscopy timing in patients with acute upper gastrointestinal bleeding. Clin Endosc. 2019; 52(1): 47-52.

18. Hwang JH, Fisher DA, Ben-Menachem T, Chandrasekhara V, Chathadi K, Decker GA, et al. The role of endoscopy in the management of acute non-variceal upper GI bleeding. Gastrointest Endosc. 2012; 75(6): 1132-8.

19. Kim JS, Kim BW, Park SM, Shim KN, Jeon SW, Kim SW, et al. Factors associated with rebleeding in patients with peptic ulcer bleeding: analysis of the Korean Peptic Ulcer Bleeding (K-PUB) Study. Gut Liver. 2018; 12(3): 271-7.

20. Guglielmi A, Ruzzenente A, Sandri M, Kind R, Lombardo F, Rodella L, et al. Risk assessment and prediction of rebleeding in bleeding gastroduodenal ulcer. Endoscopy. 2002; 34(10): 778-86.

21. de Groot NL, van Oijen MG, Kessels K, Hemmink M, Weusten BL, Timmer R, et al. Reassessment of the predictive value of the Forrest classification for peptic ulcer rebleeding and mortality: can classification be simplified? Endoscopy. 2014; 46(1): 46-52

22. Hwang JH, Fisher DA, Ben-Menachem T, Chandrasekhara V, Chathadi K, Decker GA, et al.The role of endoscopy in the management of acute non-variceal upper GI bleeding, ASGE guidline. Gastrointest Endosc. 2012; 75(6): 1132-8.

23. Park CH, Joo YE, Kim HS, Choi SK, Rew JS, Kim SJ. A prospective, randomized trial comparing mechanical methods of hemostasis plus epinephrine injection to epinephrine injection alone for bleeding peptic ulcer. Gastrointest Endosc. 2004; 60(2): 173-9.

24. Sung JJ, Barkun A, Kuipers EJ, Mossner J, Jensen DM, Stuart R, et al. Intravenouse someprazole for prevention of recurrent peptic ulcer bleeding: a randomized trial. Ann Intern Med. 2009; 150(7): 455-64.

25. Enestvedt BK, Gralnek IM, Mattek N, Lieberman DA, Eisen GM. Endoscopic therapy for peptic ulcer hemorrhage: practice variations in a multi-center US consortium. Dig Dis Sci. 2010; 55(9): 2568-76.

26. Lin HJ, Hsieh YH, Tseng GY, Perng CL, Chang FY, Lee SD. A prospective randomized trial of large versus small 
volume endoscopic injection of epinephrine for peptic ulcer bleeding. Gastrointest Endosc. 2002; 55(6): 615-9.

27. Ljubicic N, Budimir I, Biscanin A, Nikolic M, Supanc V, Hrabar D, et al. Endoclips vs large or small-volume epinephrine in peptic ulcer recurrent bleeding. World J Gastroenterol. 2012; 18(18): 2219-24.

28. Pescatore P, Jornod P, Borovicka J, Pantoflickova D, Suter W, Meyenberger C, et al. Epinephrine versus epinephrine plus fibrin glue injection in peptic ulcer bleeding: a prospective randomized trial. Gastrointest Endosc. 2002; 55(3): 348-53.
29. Lo CC, Hsu PI, Lo GH, Lin CK, Chan HH, Tsai WL, et al. Comparison of hemostatic efficacy for epinephrine injection alone and injection combined with hemoclip therapy in treating high-risk bleeding ulcers. Gastrointest Endosc. 2006; 63(6): 767-73.

30. Vergara M, Bennett C, Calvet X, Gisbert JP. Epinephrine injection versus epinephrine injection and a second endoscopic method in high-risk bleeding ulcers. Cochrane Database Syst Rev. 2014 Oct 13; (10): CD005584. doi: 10.1002/ 14651858.CD005584.pub3.

\section{Correspondence to/Autor za korespondenciju}

Eyup Gemici

University of Health Sciences, Faculty of Medicine, Bakirkoy Dr. Sadi Konuk

Health Practice\&Research Center, Department of General Surgery,

Building A, Floor 4, Tevfik Saglam Street. Nr: 11, 34147, Bakirkoy, Istanbul, Turkey

e-mail: eyupgemici@yahoo.com

phone: +9053667958 13

fax: +90212 4147171 